\title{
Concurrent Collapses of Demersal Fish and Sea Trout (Salmo trutta) on Scotland's West Coast Following the Removal of the "Three-Mile Fishing Limit"
}

\author{
Martin Jaffa* \\ Independent Researcher, Manchester M45 0FN, UK \\ ${ }^{\star}$ Corresponding Author: Dr. Martin Jaffa, Martin Jaffa, Independent Researcher, P.O. Box 497, Manchester M45 0FN, UK. Email: mrjaffa@hotmail.com
}

Received: September 19, 2019; Accepted: October 01, 2019; Published: February 14, 2020;

\begin{abstract}
The collapse of the sea trout (Salmo trutta) fishery in Loch Maree on Scotland's north west coast occurred during the late 1980s. Stocks of west coast demersal marine fish, especially around the Clyde Estuary have also declined over a similar time span. The decline of these marine fish stocks can be attributed to the removal of the "three-mile fishing limit" in 1984 by UK Government legislation. Sea trout inhabit the same inshore waters as targeted demersal fish and can be caught as unrecorded by-catch. Comparisons of the decline of demersal species and the sea trout the west coast show a high degree of correlation.
\end{abstract}

Keywords: fisheries, demersal fish, sea trout, stock collapse, three-mile fishing limit

\section{Introduction}

Catches of sea trout (Salmo trutta) using rod and line from rivers along Scotland's north west coast have been in decline since the UK Government's Scottish Office first began to collect records in 1952. Many different factors have been implicated in the decline including forestry, land use changes, acid rain, global and local climate change and overexploitation. However, attribution to any one factor is mostly anecdotal Picken [1].

Butler \& Walker [2] detailed the collapse of the world-renowned Loch Maree sea trout fishery during the late 1980s. They found that prior to 1987, annual catches of sea trout ranged between 546 and 1575 whilst from 1988 to 2001, catches fluctuated between 35 and 342, the lowest number being recorded in 2001. Butler \& Walker blame the collapse on the establishment of a salmon farm in the adjacent sea loch, Loch Ewe in 1987, but do not provide any evidence to support their claim. They state that there is no other explanation for the collapse.

In 1984, the Inshore Fishing (Scotland) Act, implemented by the Scottish Office, repealed a ban on fishing within three nautical miles of the low water mark. This "three-mile limit" had been introduced in 1889 in the interest of protecting fish stocks against overexploitation Thurstan \& Roberts [3]. The opening of inshore waters in 1984 meant that fishing vessels were able to trawl for fish along the north-west coast and within the confines of many sea lochs. This paper considers whether the removal of the "three-mile limit" may have been a significant contributory factor in the collapse of sea trout stocks in the Loch Maree fishery and elsewhere along Scotland's north-west coast.

\section{Materials \& Methods}

Examination of pre-existing data- Sea trout and the Ewe catchment including Loch Maree

Loch Maree is a $20 \mathrm{~km}$ long freshwater loch located in north-west Scotland. It is connected to Loch Ewe, a $16 \mathrm{~km}$ long sea loch by the $4 \mathrm{~km}$ long River Ewe. Loch Maree had a reputation of world renown for its sea trout angling. Records of fish catches, both numbers and weights, are collected by the holders of fishing rights and submitted to Scottish government scientists for analysis. The catch records for sea trout from 1980 onwards for the whole Ewe System are shown in Figure 1.

The bars represent the annual catch in $\mathrm{kg}$. The line represents the moving five-year average.

The decline in the number of sea trout is apparent from both the annual weight of sea trout caught and the moving five-year average.

\section{Examination of Pre-Existing Data - Demersal Fish Catches and the "Three-Mile Limit"}

Thurstan \& Roberts [3]. examined the decline of catches of marine fish such as cod (Gadus morhua), whiting (Merlangius merlangus) and saithe (Pollachius virens) from the Inner Clyde fishing grounds around Scotland's west coast. Figure 2.

\section{Collection of Data}

The Scottish Government publish catch data for sea trout and landings of demersal fish annually on the statistics section of their 
website. Catch data for sea trout was collated from all fishery districts from Ullapool to the Clyde and landings for cod, whiting and saithe for all west coast fishing ports except Kinlochbervie, which is promoted as a drop off port for distant water fishing vessels. The various data sets were analysed to ascertain the likelihood that the decline of sea trout stocks during the late 1980s including the collapse of the Loch Maree fishery might be one consequence of changes to marine fishing legislation, specifically the removal of the "three-mile limit".

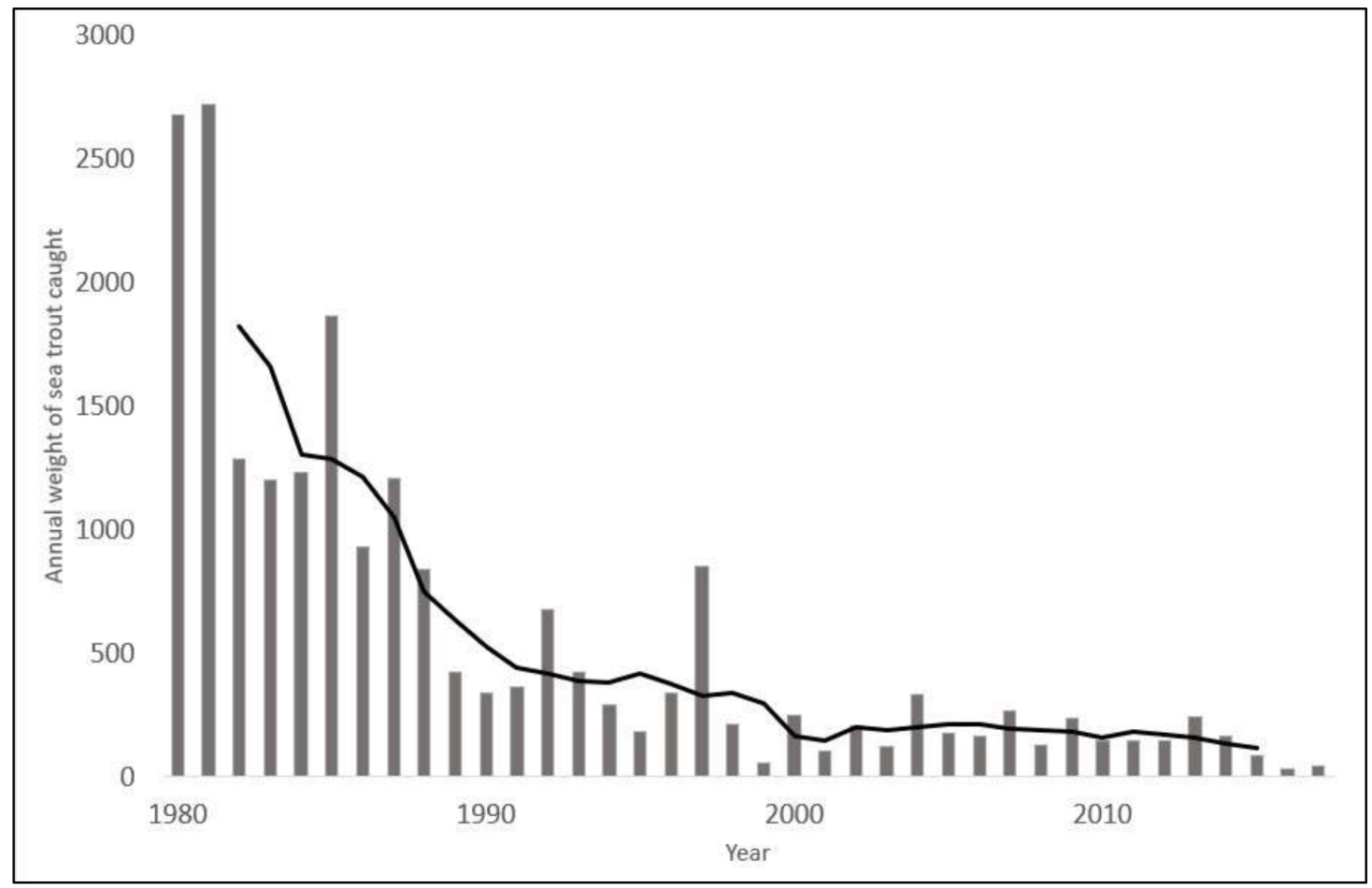

Figure 1. Annual weight of sea trout caught from the Loch Ewe catchment including Loch Maree. The bars represent the annual catch in $\mathrm{kg}$. The line represents the moving five-year average.

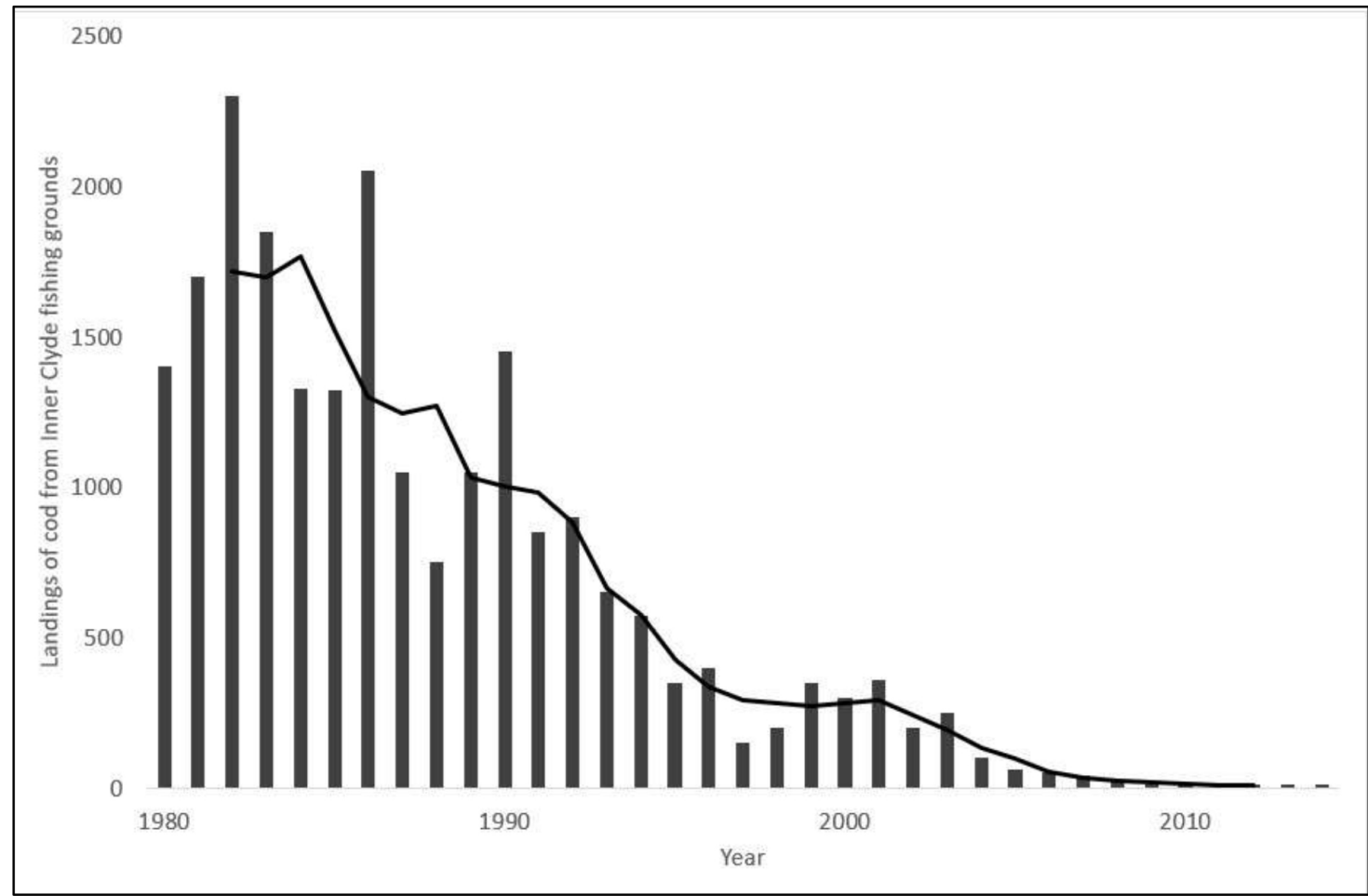

Figure 2. Comparison of cod catches from the Inner Clyde fishing grounds. The bars represent the annual catch in tonnes. The line represents the moving five-year average. The decline of cod landings from the Inner Clyde is apparent from the annual record and the five-year average. 


\section{Statistical Analysis}

\section{Regression Analyses}

One complication in analysing such data is the different ways in which information for the different species are expressed in different locations. Some data was recorded as numbers of fish, whilst other data was based around weight of fish. Given the varying numbers for different species/locations, the approach taken in the analysis was to examine the relative change in fish numbers/weight over time using simple linear regression.

$$
Y=\beta_{0}+\beta_{1} X_{1}+\epsilon
$$

Where $\beta_{0}$ is the intercept, $\beta_{1}$ represents the beta $(\beta)$ coefficient (parameter estimate), $X_{1}$ is the values of the variable in the regression model and is the error term (residuals).

Comparison of regression slopes

For comparison of the slopes, a methodology using Z-statistic has been applied.

$$
Z=\frac{b_{1}-b_{2}}{\sqrt{S E b_{1}+S E b_{2}}}
$$

Where $b_{1}$ is the slope of line $1, b_{2}$ is the slope of line $2, S E b_{1}$ is the standard error of slope 1 and $S E b_{2}$ is the standard error of the slope of line 2. The resulting $Z$-value was compared to the normal distribution to identify the statistical significance.

\section{Graphical Presentation}

All the sets of data were converted to a centred moving average and subsequently standardised to the same scale. The use of standardisation focuses on the pattern of catches rather than the actual volume.

The transformation of each variable was achieved using the formula

$$
Z=\frac{x-\bar{x}}{\sigma}
$$

Where $x$ is the volume of each fish species in a single year, $\bar{x}$ is the mean average volume of each fish species over all years and $\sigma$ is the standard deviation of volume of each fish species over all years. This will result in a variable with a mean of zero and a standard deviation of 1 .

\section{Results}

\section{Demersal Fish and the Lifting of the "Three-Mile Limit"}

In 1984, the government removed the "three-mile limit" allowing fishing boats to trawl in inshore waters around Scotland Thurstan \& Roberts [3] demonstrated that this resulted in a reduction of catches of marine demersal fish in the Inner Clyde. This is the most intensively studied area of inshore waters in Scotland, but the impacts are likely to be similar elsewhere around the Scottish coast.

\section{West Coast}

The Inner Clyde fishing grounds are located at the most southerly point of the north-west Highland region. Other fishing grounds are located along the length of the west coast with fish landed at several small fishing ports including Oban, Mallaig and Ullapool. The landings for cod, whiting and saithe are recorded by the Scottish Government and are subsequently published on the Scottish Government website.

The decline in demersal fish landed at west coast ports follows a similar pattern to the decline identified by Thurstan \& Roberts [3] from within the Inner Clyde. Opening the "three-mile limit" to inshore fishing appear to have negatively impacted the tonnage of fish caught along the whole of the Scottish west coast.

Figure 3 combines the data for the four species using a five-point centred moving average on a standardised scale of the weight of fish landed. This clearly shows the similarities between the decline of marine species and sea trout.

The data was analysed to determine the correlation between species. Sea trout is strongly correlated with $\operatorname{cod}(\mathrm{r}=0.83, \mathrm{p}<0.0001)$, whiting $(\mathrm{r}=0.88, \mathrm{p}<0.0001)$ and saithe $(\mathrm{r}=0.83, \mathrm{p}<0.0001)$.

Comparison of the rate of decline between species using regression slopes found that sea trout declined at a similar rate to $\operatorname{cod}(Z=-1.30$, $\mathrm{p}=0.1933)$ and whiting $(\mathrm{Z}=-0.34, \mathrm{p}=0.7322)$ but faster than saithe $(\mathrm{Z}=-6.90, \mathrm{p}<0.0001)$. This difference may be due to variability of different stocks in the west coast fishing grounds.

The west coast data covers the whole of the west coast excluding the furthest north. Landings of demersal can be identified from specific ports. Mallaig is an important fishing port half way up the west coast. Figure 4 shows the landings at Mallaig compared to sea trout catches as a five-point centred moving average on a standardised scale for the weight of fish landed.

The correlation between sea trout and the demersal species is less strong than for the west coast. This is not unexpected as marine fish stocks will vary along the coast due to the nature of the coastline. Sea trout is most correlated with $\operatorname{cod}(\mathrm{r}=0.68, \mathrm{p}<0.0001)$ but less correlated with whiting $(r=0.56, p=0.0005)$ and saithe $(r=0.59$, $\mathrm{p}=0.0002)$. The comparison of the rate of decline using regression lines suggests that sea trout declined at a faster rate than demersal fish around Mallaig. However, the regression line for sea trout is likely to have bene influenced by the outlying points of high numbers in 1980 and 1981. Had the data started from 1982, the rate of decline would have been less steep. The data suggests that sea trout have declined faster than $\operatorname{cod}(\mathrm{Z}=-4.01, \mathrm{p}<0.0001)$, whiting $(\mathrm{Z}=-2.17, \mathrm{p}=0.0300)$ and saithe $(\mathrm{Z}=-7.15, \mathrm{p}<0.0001)$.

\section{Nephrops Fishery}

Thurstan \& Roberts [3] chart changes to in-shore fishing catches and noted that following the collapse of demersal fish stocks in inshore waters, fishing boats have targeted Nephrops prawns. This crustacean has almost replaced demersal fish has the main catch in the Inner Clyde. Prawns are also targeted from ports around the whole Scottish coast. In 2016, Nephrops represented the second largest value 
of seafood landed at Scottish ports at $£ 79$ million with 21,000 tonnes which is greater than both cod and haddock together at $£ 65$ million. McIntyre et al. [4] highlight that the North East Atlantic Nephrops trawling fishery has been ranked as having the fifth highest discard rate in the world. In the Inner Clyde, this is estimated to be between $66 \%$ and $80 \%$. These are species that are not specifically targeted by the fishing boat and are subsequently discarded. It is not recorded whether these discards include sea trout.

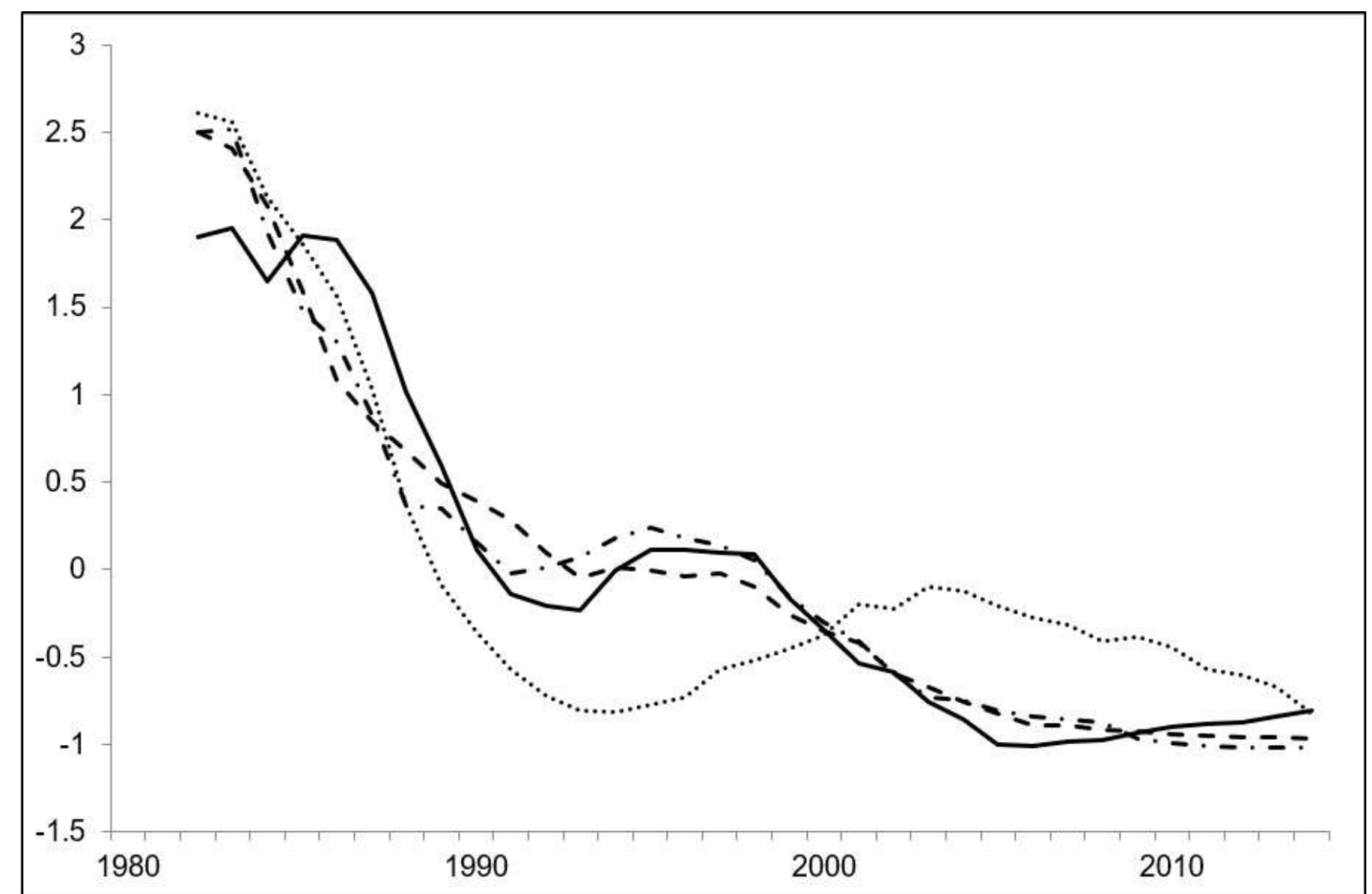

Figure 3. Five-point centred moving weight average on a standardised scale for west coast landings of cod (dashed line), whiting (dashed and dotted line), saithe (dotted line) and sea trout (solid line).

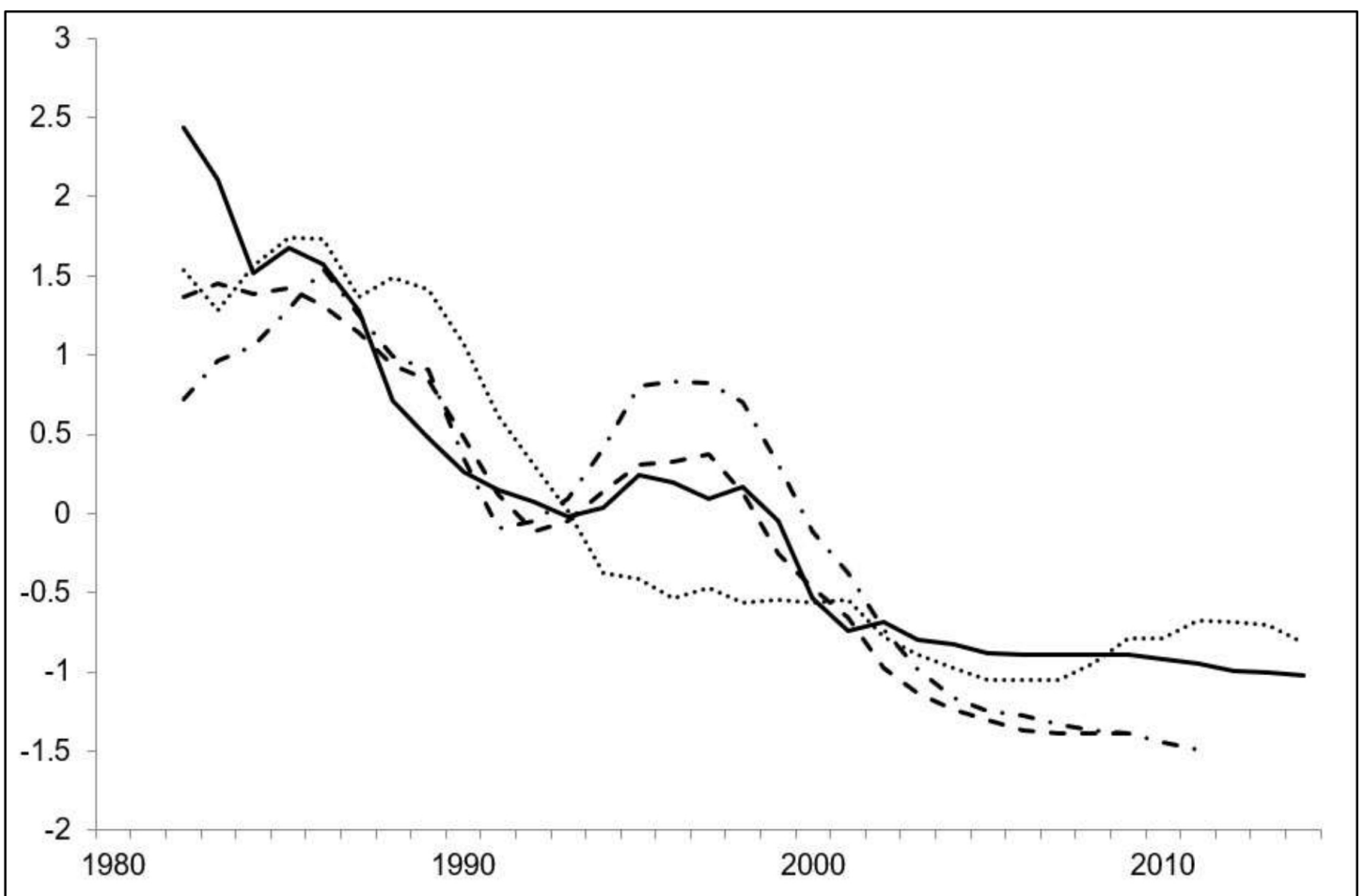

Figure 4. Five-point centred moving weight average on a standardised scale for Mallaig catches of cod (dashed line), whiting (dashed and dotted line), saithe (dotted line) and sea trout (solid line). 


\section{Discussion}

\section{Collapse of Stocks of Demersal Fish}

Thurstan \& Roberts [3] report that prior to the removal of the "three-mile limit" in 1984, catches had increased during the 1960s and 1970s because key fishing grounds around the Clyde had been opened to more efficient pair-trawling. However, these higher catches were not maintained which led to fishermen demanding help from the Government. As a result, the UK Government introduced the Inshore Fishing (Scotland) Act in 1984 which repealed a ban on trawling in inshore waters. The new legislation removed the restriction on fishing within the "three-mile limit" expanding fishing opportunities as fishermen struggled to catch enough fish to sustain their livelihoods. The Firth of Clyde, as well as other west coast inshore fishing grounds, were opened to trawling allowing exploitation of species such as cod, whiting and saithe. Yet, the reopening of the "three-mile limit" did not bring an increase in landings as between 1984 and 2009, landings decreased by $99 \%$ Hislop [5]. In addition to cod, saithe and whiting, stocks of haddock, hake, herring, flounder and plaice all showed a similar downward trajectory (Thurstan \& Roberts; McIntyre et al.) [3,4].

\section{Sea trout stocks}

There are 109 fishery districts across all of Scotland. Each is very different in nature and the number of fish caught annually. Most sea trout stocks from west coast fishery districts have shown a decline over many years. It is unclear why these stocks have declined, and several different factors have been proposed, but none are likely to be the sole reason. Instead, it is likely that there are a combination of factors bringing about these declines or else there is no obvious explaination. Sea trout catches in the Clayburn fishery district in the Outer Hebrides collapsed in 1976 and have never recovered. There has been no scientific investigation into this collapse, and the cause remains unknown

\section{Relationship Between Sea Trout and Demersal Stock Collapses}

The decline of sea trout catches from Scotland's west coast strongly correlates with declines of landings of marine demersal fish at west coast fish ports with similar declines of saithe, cod and whiting. Whilst correlation does not equate to causation, the loss of marine fish can be attributed to the removal of the "three-mile limit" in 1984 which allowed fishing boats to trawl in inshore waters including sea lochs. Although sea trout stocks were already in decline, the removal of the "three-mile fishing limit" provides a plausible explanation as to cause of the collapse of the Loch Maree sea trout fishery Walker AF [6].

\section{Significance Statement}

Sea trout catches by rod and line have been in decline along the Scottish west coast since records began in 1952. No specific reason has been identified for the decline. During the 1980s, the worldrenowned sea trout fishery in Loch Maree collapsed. The cause of this collapse also remains unexplained. This research has identified similarities between the collapse of demersal fish stocks and sea trout following the removal of the three-mile limit in 1984.

\section{References}

1. Picken MJ (1990) The Sea Trout in Scotland. Symposium Proceedings. Scottish Marine Biological Association: 53-59.

2. Butler JRA, Walker AF (2006) Characteristics of the Sea Trout (Salmo trutta) Stock Collapse in the River Ewe (Wester Ross Scotland), in 1988-2001. In Sea Trout: Biology, Conservation and Management. Edited by Harris, G. \& Milner, N. Blackwell Publishing Page: 45-59.

3. Thurstan RH, Roberts CM (2010) Ecological meltdown in the Firth of Clyde, Scotland, Two centuries of change in a coastal marine ecosystem. PLos ONE 5.

4. McIntyre F, Fernandes PG, Turrell WR (2012) Clyde Ecosystem Review. Scottish Marine and Freshwater Science: 3

5. Hislop JRG (1986) The demersal fishery in the Clyde sea area. Proc. Roy. Soc. 90: $423-437$.

6. Walker AF (2006) The rapid establishment of a resident brown trout population from sea trout progeny in a fishless stream. In: Sea Trout Biology, Conservation \& Management (Harris, G.S. \& Milner N.J. eds). Proceedings of the First International Sea Trout Symposium. July 2004. Cardiff, Wales. Blackwell Publishing Oxford: 389-400.

\section{Citation:}

Martin Jaffa (2019) Concurrent Collapses of Demersal Fish and Sea Trout (Salmo trutta) on Scotland's West Coast Following the Removal of the "ThreeMile Fishing Limit". Aquac Fish Stud Volume 1(1): 1-5. 